\title{
PENGARUH PEMBELAJARAN IPA BERBASIS SETS \\ TERHADAP CROSS DISCIPLINARY KNOWLEDGE PESERTA DIDIK
}

\author{
Rini Budiarti'; Jumadi²; Insih Wilujeng $^{2}$; dan Senam ${ }^{2}$ \\ ${ }^{1}$ SMP Islam Athirah Makassar; ${ }^{2}$ Universitas Negeri Yogyakarta \\ 1email: bioribud@gmail.com
}

\begin{abstract}
Abstrak: Penelitian ini bertujuan untuk mengungkapkan pengaruh pembelajaran IPA berbasis SETS terhadap cross disciplinary knowledge peserta didik kelas VII SMP. Penelitian ini merupakan penelitian kuasi eksperimen dengan populasi SMP di Makassar yang menerapkan Kurikulum 2013. Sampel diambil sebanyak 3 sekolah yang dipilih berdasarkan stratifikasi yang mewakili sekolah kategori tinggi, sedang, dan rendah. Penentuan kelas eksperimen dan kontrol pada masing-masing sekolah dilakukan dengan teknik cluster random sampling. Instrumen yang digunakan adalah tes dengan bentuk soal pilihan majemuk beralasan. Analisis data menggunakan independent sample t- test serta uji U-mann whitney. Hasil penelitian menunjukkan bahwa pada sekolah SMP kategori tinggi dan sedang, capaian cross disciplinary knowledge kelompok eksperimen yang mendapatkan pembelajaran IPA berbasis SETS rata-rata lebih tinggi secara signifikan dibandingkan dengan kelompok kontrol yang mendapatkan pembelajaran IPA konvensional, sedangkan pada sekolah kategori rendah capaian cross disciplinary knowledge kelompok eksperimen dan kontrol tidak berbeda secara signifikan.
\end{abstract}

Kata kunci: pembelajaran IPA, SETS, cross disciplinary knowledge

\section{THE EFFECT OF SCIENCE LEARNING-BASED ON SETS THROUGH STUDENTS' CROSS DISCIPLINARY KNOWLEDGE}

\begin{abstract}
The purpose of this study is to reveal the effectof SETS-basedscience learning on the cross disciplinary knowledge of the $7^{\text {th }}$ grade students of junior high schools in Makassar. This study belongs toquasi-experimental research involving the population of junior high schools in Makassar that apply the Curriculum 2013. The sample involves three schools from different categories, i.e. high, intermediate, and low. The experimental and control classes in each school were selected through cluster random sampling technique. The instruments used in this research were multiple choice questions test with reason. Data were analyzed using independent sample t-test and Mann Whitney U-test. The results show that at the high and middle junior high schools, the achievement of cross disciplinary knowledge of the experimental group receiving SETS-based science teachingis significantly higher than that of the control group receiving conventional science teaching, whereas at the lower junior high schools, the achievement of cross-disciplinary knowledge experimental group receiving the science teaching based on SETSis not higher than that of the control group receiving conventional science teaching.
\end{abstract}

Keywords: SETS, cross disciplinary knowledge

\section{PENDAHULUAN}

Generasi saat ini dihadapkan pada perubahan dan perkembangan zaman yang menuntut kemampuan berkompetisi terhadap persaingan lokal, nasional maupun global. Oleh karena itu, dunia pendidikan kini dihadapkan pada tantangan untuk mempersiapkan generasi yang memiliki kompetensi abad ke-21. Semakin banyak penelitian terkait kompetensi abad ke-21 yang dilakukan baik terhadap pendidik, peserta didik, maupun sistem pendidikan. Kereluik et al. (2013:130) menyatakan bahwa kompetensi abad ke-21 terdiri dari foundational knowledge, metaknowledge dan humanistic knowledge. Foundational knowledge terdiri atas subkategori cross disciplinary knowledge, core content knowledge, serta digital/ict literacy. Bagan mengenai kompetansi abad ke-21 ditunjukkan pada Gambar 1. 


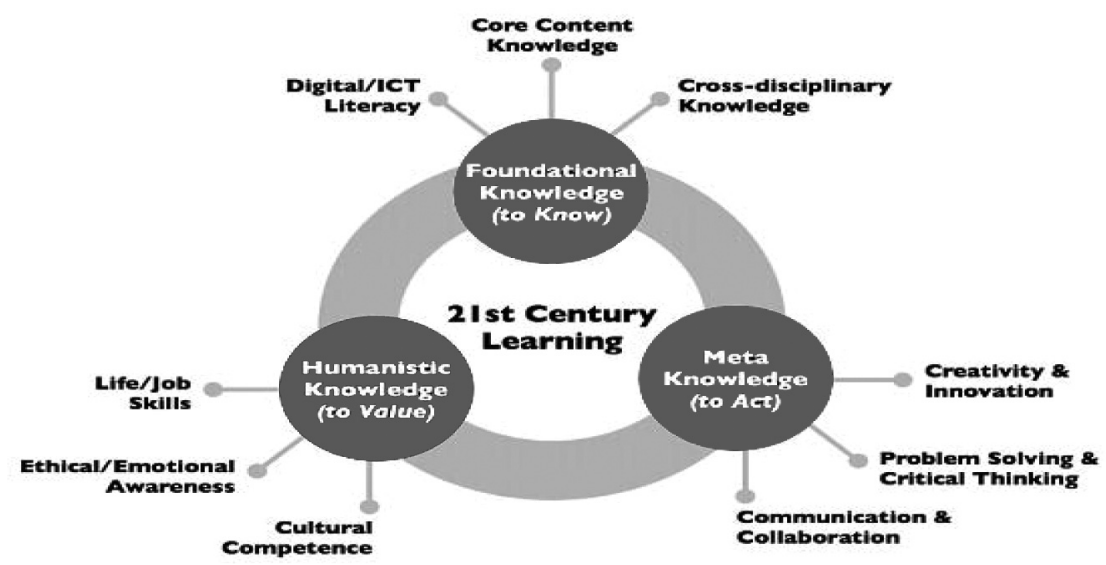

Gambar 1. Kompetensi Abad XXI

(sumber: Kereluik et al, 2013:130)

Cross disciplinary knowledge merupakan pengetahuan yang mengintegrasikan dan menyintesis informasi dari berbagai bidang kajian ilmu (Kereluik et al., 2013:130). Banyak masalah, fenomena, serta konsep yang penting, namun kompleks yang sulit untuk dipahami atau dipecahkan ketika menggunakan pendekatan satu disiplin ilmu (Golding, 2009:2). Dengan demikian, pengetahuan lintas disiplin ilmu sangat penting untuk dilatihkan kepada peserta didik,

Istilah untuk pengintegrasian beberapa disiplin ilmu diantaranya adalah cross disciplinary, interdisciplinary, multidisciplinary, transdisciplinary, fusion, serta parallel discipline (Drake, 2012:25-26; Nordahl \& Serafin, 2008:94; Demirel \& Co ${ }^{\circ}$ ku, 2010:31). Penjelasan beberapa ahli mengenai hirarki keterpaduan disiplin ilmu memberikan kesimpulan yang kurang lebih sama, yakni cross disciplinary knowledge memberikan dasar pada pengintegrasian disiplin ilmu yang lebih luas dan kompleks. Cross disciplinary knowledge sebagai pengetahuan lintas disiplin ilmu diperlukan untuk menjawab isu dan permasalahan yang terkait sains, lingkungan, teknologi dan masyarakat yang biasanya bersifat kompleks dan sulit dipahami.

Salah satu model pembelajaran yang dapat mengangkat isu terkait sains, lingkungan, teknologi dan masyarakat adalah pendekatan SETS (Science, technology and society). SETS lahir dari istilah STS dengan penambahan unsur environment atau lingkungan. Berdasarkan sejarah perkembangan pendidikan IPA di Amerika, istilah STS muncul pada akhir revolusi pertama pendidikan IPA di Amerika, yaitu sekitar tahun 1978 (McCormack, 1992:18-21). Pada saat itu mulai banyak sekolah yang menerapkan pen- didikan sains, teknologi, dan masyarakat dalam kurikulum.

STS mengalami perkembangan istilah yang beragam di berbagai negara. Perkembangan istilah ini dilatarbelakangi oleh keberagaman budaya, tradisi, serta konsep yang mendasari. Di Kanada, lingkungan dianggap penting dan menjadi penekanan dalam pembelajaran berbasis STS sehingga istilah STS berubah menjadi STSE dengan penambahan unsur 'Environment' atau lingkungan. Di Belgia unsur etnik dimasukan dalam pembelajaran STS sehingga istilah yang berkembang adalah STES atau Science, Technology, Ethnics and Society. Istilah lain di beberapa negara diantaranya adalah Science, Technology and Citizenship; Nature, Technology, Society; Science for Society Approach; Functional Science Literacy, serta Social Awareness (Yörük, Morgil, \& Seçken, 2010:1418).Di Indonesia istilah STS lebih dikenal dengan istilah Sains Teknologi Masyarakat (STM). STM kemudian berkembang menjadi "Sains Lingkungan Teknologi dan Masyarakat" atau yang biasa diakronimkan dengan istilah "salingtemas". Salingtemas memiliki makna yang sama dengan SETS.

Pembelajaran dengan pendekatan SETS di beberapa negara mengacu pada karakteristik penting yang ditetapkan oleh NSTA (Yager et al, 2006:249; Yager \& Akcay, 2008:2; Yager et al. 2009: 17; Yager et al.2012:4). Karakterisktik penting dalam pendekatan STS menurut NSTA adalah sebagai berikut. Pertama, Peserta didik mengidentifikasi masalah yang terjadi sekitar beserta dampaknya. Kedua, Menggunakan potensi lokal untuk memperolah informasi yang dapat digunakan untuk memecahkan masalah. Ketiga, Keterlibatan peserta didik secara aktif dalam 
mencari informasi yang dapat digunakan untuk memecahkan masalah dunia nyata. Keempat, Penambahan jam belajar di luar waktu belajar di kelas dan di sekolah. Kelima, Fokus pada dampak sains dan teknologi yang terjadi pada peserta didik. Keenam, Pandangan bahwa konten IPA lebih dari sekedar konsep yang hanya dipakai untuk kepentingan tes. Ketujuh, Menekankan pada keterampilan proses yang dapat digunakan peserta didik untuk memecahkan masalah. Kedelapan, Menekankan pada kesiapan karir terutama karir yang berhubungan dengan sains dan teknologi. Kesembilan, Memperi kesempatan pada peserta didik untuk berperan sebagai warganegara yang dapat menyelesaikan isu yang telah mereka identifikasi. Kesepuluh, Mengidentifikasi bahwa sains dan teknologi akan berdampak pada masa depan. Kesebelas, Peserta didik belajar secara mandiri dalam mengidentifikasi isu.

Banyak keuntungan yang dapat diperoleh melalui pembelajaran berbasis SETS. Wilujeng (2011:6) menyatakan bahwa pembelajaran SETS yang diaplikasikan di kelas oleh seorang guru akan mampu mengubah proses berpikir peserta didik karena pengetahuan sains dan teknologi dibelajarkan dengan aplikasi prinsip-prinsip sains dan teknologi serta dampaknya pada masyarakat dan lingkungan. Selain itu pembelajaran berbasis SETS dapat melatih kemampuan berpikir kreatif tentang aplikasi sains dalam pemecahan masalah, sehingga pelajaran tidak membosankan (Avci, Onal, \& Usak (2014:217). Hasil penelitian yang dilakukan oleh Rosario (2009:269) serta Yörük et al. (2010:1417) menunjukkan bahwa pembelajaran berbasis SETS terbukti dapat meningkatkan hasil belajar peserta didik. Penelitian relevan lalinnya adalah penelitian pengembangan yang dilakukan oleh Setiawati (2015) yang salah satu hasil penelitiannya menyebutkan bahwa perangkat pembelajaran IPA berbasis SETS terbukti efektif dalam meningkatkan foundational knowledge peserta didik dalam hal cross disciplinary knowledge.

Ciri khas dari pembelajaran IPA berbasis SETS adalah menghadirkan isu ke dalam pembelajaran. Pentingnya menghadirkan isu yang kontroversial ke dalam pembelajaran dikemukakan oleh Wellington \& Ireson (2012:269), diantaranya adalah: (1) cara yang bisa membuat materi menjadi menarik, bermakna, menakjubkan dan relevan sehingga dapat meningkatkan motivasi peserta didik; (2) cara untuk menggambarkan IPA yang sesungguhnya, misalnya konsep IPA yang tidak selamanya pasti, benar, dapat dipercaya dan tanpa masalah; (3) peserta didik dapat memperoleh nilai, keterampilan proses serta pemahaman tentang isu kontroversi yang berhubungan dengan sains.

Pembelajaran IPA berbasis SETS yang menghadirkan isu dalam pembelajaran secara tidak langsung dapat melatih siswa dalam mengaitkan dan mengintegrasikan suatu konsep dengan kosep lain, dengan topik lain, atau bahkan dengan disiplin ilmu lain. Pengintegrasian beberapa topik maupun konsep dengan beberapa disiplin ilmu yang terkait akan membuat pembelajaran lebih menarik dan bermakna, sehingga anak akan lebih memahami suatu topik atau konsep dari berbagai sudut pandang, terampil membuat perbandingan dan membuat hubungan (Howe \& Jones, 1993:321). Pengintegrasian topik maupun konsep dalam pembelajaran memberikan keuntungan juga terhadap guru, seperti membantu guru untuk belajar lebih banyak pada tema yang lebih luas, bahkan jika memungkinakan guru dapat memberikan contoh ketika berkolaborasi dengan bidang studi lain (Hilburn \& Wall, 2011:2).

Pembelajaran IPA berbasis SETS sangat berkaitan dengan cross disciplinary knowledge. Akan tetapi studi pendahuluan terhadap beberapa sekolah di kota Makassar menunjukkan bahwa guru masih jarang menggunakan pembelajaran IPA berbasis SETS. Oleh karena itu diperlukan suatu penelitian eksperimen untuk membuktikan bahwa pembelajara IPA berbasis SETS memiliki pengaruh yang positif terhadapcross disciplinary knowledge peserta didik.

\section{METODE}

Penelitian ini merupakan penelitian kuasi eksperimen dengan populasi SMP di kota Makassar yang menerapkan Kurikulum 2013. Adapun sampel penelitian sebanyak tiga sekolah ditetapkan berdasarkan stratifikasi sekolah, yaitu sekolah kategori tinggi, sedang dan rendah. Kategori stratifikasi sekolah didasarkan atas modus dari rata-rata nilai IPA pada ujian nasional (UN) tahun 2013, 2014, dan 2015. Melalui pengundian sederhana, diperoleh sampel yaitu SMP 12 Makassar untuk sekolah kategori tinggi, SMP Islam Athirah untuk kategori sedang dan SMPN 3 Makassar untuk kategori rendah. Penentuan kelas eksperimen dan kelas kontrol pada masing-masing sekolah dilakukan dengan caracluster random sampling. Kelas eksperimen merupakan kelas yang menda- 
pat pembelajaran IPA berbasis SETS, sedangkan kelas kontrol merupakan kelas yang mendapat pembelajaran IPA konvensional.

Pembelajaran IPA berbasis SETS dalam penelitian ini dilakukan dalam rangka implementasi Kurikulum 2013 dengan tetap memperhatikan aspek pendekatan saintifik. Oleh karena itu unsur yang terdapat dalam pembelajaran IPA berbasis SETS dalam penelitian ini terdiri dari mengamati, menanya, dan menganalisi isu SETS serta menyajikan dan mempresentasikan. Adapun indikator ketercapaian cross disciplinary knowledge peserta didik terdiri dari mengidentifikasi ide dalam aspek SETS, menggunakan metode divergen dan konvergen untuk menyeleksi dan mengelompokkan ide yang muncul, serta menggunakan model connected antar aspek SETS.

Instrumen yang digunakan untuk mengukur capaian cross disciplinary knowledge dalam penelitian ini adalah 24 butir soal pilihan majemuk beralasan.Instrumen diadopsi dari instumen penelitian Setiawati (2015) dengan nilai validitas oleh dosen ahli berada pada kategori baik dan validitas oleh pendidik IPA berada pada kategori sangat baik. Adapun reabilitas soal yang dianalisis dengan menggunakan Winstep menunjukkan hasil item reability sebesar 0,88 (kategori baik), pearson reability sebesar 0,89 (kategori baik), serta nilai alpha cronbach sebesar 0,91 (kategori sangat baik).

Disain penelitian yang digunakan adalah pre and posttest design. Sebelum dan setelah dilaksanakan pembelajaran, masing-masing kelas diberikan pretes dan postes untuk mengukur capaian cross disciplinary knowledge sebelum dan setelah treatment. Jika hasil analisis data pretes menunjukkan tidak adanya perbedaan yang signifikan antara kelas eksperimen dan kontrol, maka pengaruh treatment hanya dilihat dari hasil postes, namun jika terdapat perbedaan yang signifikan maka pengaruh treatment dapat dilihat melalui analisis nilai gain (pretes dikurangi postes).

Teknik analis data yang digunakan adalah uji t (parametrik) atau uji U-mann whitney (nonparametrik). Uji parametrik menyaratkan terpenuhinya asumsi dasar, yaitu normalitas dan homogenitas data. Uji normalitas menggunakan uji Shapiro-Wilk, sedangkan uji homogenitas menggunakan Lavene's test. Jika asumsi dasar terpenuhi, data diolah dengan uji $\mathrm{t}$, namun jika asumsi dasar tidak terpenuhi, data diolah dengan uji U-mann whitney. Semua uji dianalisis meng- gunakan bantuan program SPSS 22 for Windows. Taraf signifikansi yang digunakan adalah $\alpha=$ 0,05 .

Hipotesis nol adalah capaian cross disciplinary knowledge peserta didik yang mendapat pembelajaran IPA berbasis SETS tidak lebih tinggi dari pada pembelajaran konvensional, sedangkan hipotesis alternatifnya adalah capaian cross disciplinary knowledge peserta didik yang mendapat pembelajaran IPA berbasis SETS lebih tinggi dari pada pembelajaran konvensional. Kriteria keputusannya adalah $\mathrm{H}_{0}$ ditolak jika sig $<\alpha$. Jika $\mathrm{H}_{0}$ ditolak, hal itu berarti capaian cross disciplinary knowledge peserta didik yang menggunakan pembelajaran IPA berbasis SETS lebih tinggi daripada pembelajaran konvensional.

\section{HASIL DAN PEMBAHASAN Hasil}

Kemampuan awal peserta didik dalam hal cross disciplinary knowledge dapat dilihat melalui analisis data pretes.Deskripsi data hasil pretesditunjukkan pada Tabel 1.

Tabel 1. Deskripsi Data Pretest

\begin{tabular}{llcccc}
\hline Nama Sekolah & Kelas & Mean & SD & $\begin{array}{c}\text { Skor } \\
\text { Maks }\end{array}$ & $\begin{array}{c}\text { Skor } \\
\text { Min }\end{array}$ \\
\hline SMPN 12 & Eks & 30,60 & 12,59 & 63 & 4 \\
Makassar & Kon & 28,52 & 12,68 & 58 & 4 \\
SMP Islam & Eks & 32,50 & 13,25 & 58 & 8 \\
Athirah Mks & Kon & 38,35 & 10,88 & 58 & 17 \\
SMPN 3 & Eks & 26,14 & 12,24 & 58 & 8 \\
Makassar & Kon & 26,28 & 14,01 & 54 & 0 \\
\hline
\end{tabular}

Data pretes selanjutnya diuji normalitas dan homogenitasnya. Hasil uji normalitas dengan Shapiro-Wilk test menunjukkan hasil bahwa seluruh data dari tiga sekolah berdistribusi normal. Demikian juga dengan uji homogenitas Lavene's yang memberikan hasil bahwa data dari tiga sekolah seluruhnya homogen. Dengan demikian asumsi untuk uji parametrik telah terpenuhi.

Setelah uji asumsi terpenuhi, analisi data pretes dilanjukan dengan uji t. Hasil uji t data pretes diperlihatkan pada Tabel 2.

Tabel 2. Hasil Uji t Data Pretest

\begin{tabular}{lcc}
\hline \multicolumn{1}{c}{ Nama Sekolah } & Nilai sig & Keputusan \\
\hline SMPN 12 Makassar & 0,529 & $\mathrm{H}_{0}$ diterima \\
SMP Islam Athirah Makassar & 0,094 & $\mathrm{H}_{0}$ diterima \\
SMPN 3 Makassar & 0,865 & $\mathrm{H}_{0}$ diterima \\
\hline
\end{tabular}

Nilai signifikansi yang lebih besar dari $\alpha$ pada seluruh sampel sehingga $\mathrm{H}_{0}$ diterima. De- 
ngan demikian, dapat disimpulkan bahwa tidak ada perbedaan yang signifikan antara kelas eksperimen dan kelas kontrol dalam hal cross disciplinary knowledge. Dengan kata lain, kemampuan awal peserta didik sama. Oleh karena itu, untuk melihat pengaruh treatment terhadap cross disciplinary knowledge cukup dilakukan dengan cara melakukan analisis data postes. Deskripsi data postes ditunjukkan pada Tabel 3.

Tabel 3. Deskripsi DataPost-test

\begin{tabular}{llcccc}
\hline Nama Sekolah & Kelas & Mean & SD & $\begin{array}{c}\text { Skor } \\
\text { Maks }\end{array}$ & $\begin{array}{c}\text { Skor } \\
\text { Min }\end{array}$ \\
\hline SMPN 12 & Eks & 50,53 & 14,38 & 71 & 21 \\
Makassar & Kon & 41,88 & 14,33 & 67 & 17 \\
SMP Islam & Eks & 56,75 & 15,63 & 88 & 25 \\
Athirah Mks & Kon & 43,38 & 13,16 & 79 & 21 \\
SMPN 3 & Eks & 54,14 & 15,94 & 83 & 25 \\
Makassar & Kon & 38,28 & 18,66 & 92 & 25 \\
\hline
\end{tabular}

Data postes selanjutnya diuji normalitas dan homogenitasnya. Uji Shapiro-Wilk menunjukkan hasil bahwa datapostes SMPN 12 Makassar dan SMP Islam Athirah berdistribusi normal, sedangkan data postes SMPN 3 Makassar tidak berdistribusi normal sehingga uji hipotesis untuk SMPN 3 Makassar menggunakan uji U-mann whitney. Adapun data post-test SMPN 12 Makaassar dan SMPN 3 Makassar selanjutnya diuji homogenitasnya dengan uji lavene's. Uji lavene's menunjukkan hasil bahwa data post-test SMPN 12 Makassar dan SMP Islam Athirah Makassar adalah homogen. Data SMPN 12 Makassar dan SMP Islam Athirah Makassar selanjutnya diuji dengan uji t karena asumsi dasar telah terpenuhi. Ringkasan hasil uji hipotesis pada ketiga sekolah sampel diperlihatkan padaTabel 4.

Tabel 4. Hasil Uji Hipotesis Data Postes

\begin{tabular}{llcl}
\hline Nama Sekolah & Nama Uji & $\begin{array}{c}\text { Nilai } \\
\text { sig }\end{array}$ & Keputusan \\
\hline $\begin{array}{l}\text { SMPN 12 } \\
\text { Makassar }\end{array}$ & Uji t & 0,019 & $\mathrm{H}_{0}$ ditolak \\
$\begin{array}{l}\text { SMP Islam } \\
\text { Athirah Makassar }\end{array}$ & Uji t & 0,001 & $\mathrm{H}_{0}$ ditolak \\
$\begin{array}{l}\text { SMPN 3 } \\
\text { Makassar }\end{array}$ & $\begin{array}{l}\text { U-mann } \\
\text { whitney }\end{array}$ & 0,920 & $\mathrm{H}_{0}$ diterima \\
\hline
\end{tabular}

Berdasarkan hasil analisis uji hipotesis, dapat diketahui bahwa data SMPN 12 Makassar dan SMP Islam Athirah memiliki nilai signifikansi yang lebih kecil dari $\alpha$. Oleh karena itu, $\mathrm{H}_{0}$ ditolak. Dengan demikian, dengan menggunakan $\alpha=0,05$ dapat disimpulkan bahwa pada kategori sekolah tinggi dan sedang, capaian hasil belajar aspek cross disciplinary knowledge peserta didik yang memperoleh pembelajaran IPA berbasis SETS lebih tinggi dari pada kelompok peserta didik yang mendapat pembelajaran IPA konvensional.

Data post-test SMPN 3 Makassar setelah diolah dengan uji U-mann whitney menghasilkan signifikansi sebesar 0,920 atau lebih besar dari pada $\alpha$, sehingga $\mathrm{H}_{0}$ diterima. Dengan demikian, dengan menggunakan $\alpha 0,05$ dapat disimpulkan bahwa pada sekolah kategori bawah, capaian hasil belajar aspek cross disciplinary knowledge peserta didik yang medapat pembelajaran IPA berbasis SETS tidak lebih tinggi dari peserta didik yang mendapat pembelajaran IPA konvensional. Deskripsi rata-rata capaian cross disciplinary knowledge peserta didik pada ketiga sekolah ditunjukkan oleh grafik pada Gambar 2.

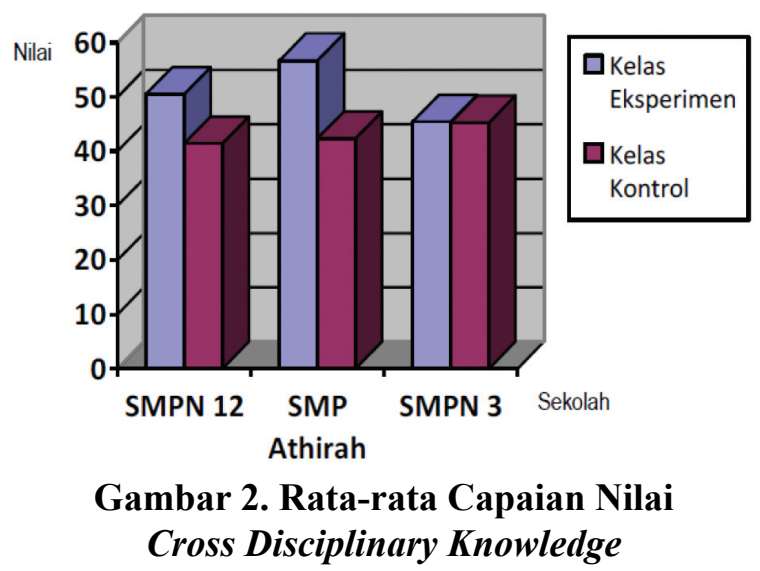

\section{Pembahasan}

Pengaruh SETS yang signifikan terhadap cross disciplinary knowledge pada SMPN 12 dan SMP Islam Athirah menguatkan pendapat Howe \& Jones (1993:321) yang menyatakan bahwa pengintegrasian beberapa topik maupun konsep dengan beberapa disiplin ilmu yang terkait akan membuat pembelajaran lebih menarik dan bermakna, sehingga anak akan lebih memahami suatu topik atau konsep dari berbagai sudut pandang, terampil membuat perbandingan dan membuat hubungan. Hasil penelitian ini juga menguatkan hasil penelitian sebelumnya. Hasil penelitian yang dilakukan oleh Rosario (2009:269) serta Yörük et al. (2010:1417) menunjukkan bahwa pembelajaran berbasis SETS terbukti dapat meningkatkan hasil belajar peserta didik. Penelitian relevan lainnya yang menguatkan hasil penelitian ini adalah penelitian pengembangan yang dilakukan oleh Setiawati (2015) yang salah satu hasil penelitiannya menyebutkan bahwa perangkat pembelajaran 
IPA berbasis SETS terbukti efektif dalam meningkatkan foundational knowledge peserta didik dalam hal cross disciplinary knowledge.

Pembelajaran IPA berbasis SETS secara tidak langsung telah dapat mengintegrasikan beberapa konsep dengan disiplin ilmu yang terkait. Misalnya pada isu terkait dampak kenaikan harga bahan bakar minyak (BBM), peserta didik akan berdiskusi tidak hanya pada disiplin ilmu IPA terkait keterbatasan sumber energi, tetapi juga akan terhubung dengan disiplin ilmu lainnya seperti IPS dan PKn terkait dengan pembahasan mengenai dampak sosial ekonomi serta kebijakan pemerintah akan kenaikan harga BBM.

Pembahasan khusus untuk SMP Negeri 3 Makassar yang mewakili sekolah kategori bawah, penyebab rendahnya capaian cross disciplinary knowledge peserta didik pada kelas eksperimen bisa saja disebabkan karena kurangnya minat baca peserta didik. Hasil temuan di lapangan memperlihatkan bahwa umumnya peserta didik terlihat antusias ketika isu SETS ditampilkan pada awal pelajaran, namun ketika lembar kerja dibagikan, sebagian besar peserta didik enggan membaca dan memperhatikan petunjuk yang ada pada lembar kerja. Pemahaman akan petunjuk yang ada pada lembar kerja akan berpengaruh terhadap hasil diskusi dan penguasaan konsep. Oleh karena itu, minat baca peserta didik berpengaruh terhadap hasil belajar.

Hasil penelitian terkait dengan minat baca peserta didik adalah penelitian yang dilakukan oleh Fang \& Wei (2010) yang meneliti pengaruh membaca terhadap sciencitif literacy peserta didik sekolah menengah. Kelas kontrol mendapat pembelajaran inquiri, sedangkan kelas eksperimen mendapat perlakuan pembelajaran ikuiri plus kegiatan membaca. Hasil penelitian menunjukkan bahwa kegiatan membaca memberi pengaruh yang positif terhadap peningkatan scientific literacy peserta didik sekolah menengah.

Jika melihat rata-rata capaian cross disciplinary knowledge pada ketiga sekolah, dapat dikatakan hasil belajar siswa masih rendah, karena masih dibawah kriteria ketuntasan minimal yang biasanya ditetapkan oleh sekolah yaitu 75 . Salah satu faktor yang berpengaruh terhadap rendahnya hasil belajar peserta didik yaitu tidak terbiasanya pendidik dan peserta didik dengan kegiatan pembelajaran IPA berbasis SETS. Unsurunsur yang ada dalan pembelajaran IPA berbasis SETS akan memberi pengaruh yang besar jika telah menjadi pembiasaan. Akan tetapi pendidik umumnya lebih memilih untuk tidak menggunakan model SETS, seperti yang terungkap dalam wawancara pada studi pendahuluan. Hal ini sesuai dengan penelitian yang dilakukan oleh Avci, Onal, \& Usak (2016). Hasil penelitian yang dilakukan oleh Avci, Onal, \& Usak (2014:2016) mengungkapkan bahwa kebanyakan guru enggan menerapkan pembelajaran berbasis SETS karena menghabiskan banyak waktu dan peralatan, serta membuat suasana kelas menjadi gaduh.

\section{PENUTUP}

Hasil penelitian ini menunjukkan bahwa pada sekolah SMP kategori tinggi dan sedang di Kota Makassar, capaian cross disciplinary knowledge kelompok eksperimen yang mendapatkan pembelajaran IPA berbasis SETS rata-rata lebih tinggi secara signifikan dibandingkan dengan kelompok kontrol yang mendapatkan pembelajaran IPA konvensional, sedangkan pada SMP kategori rendah capaian cross disciplinary knowledge kelompok eksperimen yang mendapatkan pembelajaran IPA berbasis SETS rata-rata tidak lebih tinggi dibandingkan dengan kelompok kontrol yang mendapatkan pembelajaran IPA konvensional.

Pembelajaran IPA berbasis SETS sebaiknya dapat menjadi alternatif model pembelajaran dalam implementasi kurikulum 2013, karena terbukti dapat memberi pengaruh yang posistif terhadap cross disciplinary knowledge yang sangat diperlukan untuk terwujudnya kompetensi abad 21. Oleh karena itu pendidik hendaknya dapat memahami dan mengimplementasikan pembelajaran IPA berbasis SETS. Berdasarkan temuan di lapangan, banyak hal yang diduga berpengaruh terhadap hasil penelitian ini. Oleh karena itu diperlukan suatu penelitian lanjutan untuk mengetahui faktor lain yang berpengaruh terhadap capaian cross disciplinary knowledge peserta didik.

\section{UCAPAN TERIMA KASIH}

Ucapan terima kasih disampaikan kepada para pembimbing yang telah berkenan memberikan arahan dan bimbingan untuk penyempurnaan artikel ini. Ucapan terima kaish juga disampaikan kepada kepala sekolah dan para guru di SMPN 12 Makasar, SMP Islam Athirah, dan SMPN 3 Makasar yang membantu proses penelitian ini. Harapannya, artikel ini bermanfaat bagi upaya pengembangan proses pembelajaran di sekolah. 


\section{DAFTAR PUSTAKA}

Avci, D. E., Onal, N. S., \& Usak, M. 2014. Turkish Tea - chers' Opinions about Science - Technology - Society - Environment Acquisitions in Science and Technology Course Curriculum. Journal of Baltic Science Education, 13(2), 216 - 230.

Demirel, M., \& Co ${ }^{\circ}$ kun, Y. D. 2010. Case Study on Interdisciplinary Teaching Approach Support by Project Base Learning. The International Journal of Research in Teacher Education, 2(3), 28-53.

Drake, M. S. 2012. Creating Standards - Base Integrated Curriculum. Corwin, California.

Fang, Z., \& Wei, Y. 2010. Improving Middle School Students' Science Literacy Through Reading Infusion. The Journal of Educational Research(103), 262-273.

Golding, C. 2009. Integrating the disciplines: Successful interdisciplinary subjects. CSHE - The University of Melbourne, Melbourne.

Hilburn, J., \& Wall, S. D. 2011. Concept - Base Interdisciplinary Teaching: Science and Social Studies Teacher Collaboration for the 21st Century. North Carolina Middle School Association Journal, 26(1), 1-10.

Howe, C. A., \& Jones, L. 1993. Engaging Children in Science. Macmillan Publishing Company, New York.

Kereluik, K., Mishra, P., Fahnoe, C., \& Terry, L. 2013. What Knowledge Is of Most Worth: Teacher Knowledge for 21 st Century Learning. Journal of Digital Learning in Teacher Education, 29(4), 127-140.

McCormack, A. J. 1992. Trends and Issues in Science Curriculum. Kraus International Publication, New York.

Nordahl, R., \& Serafin, S. 2008. Using problem based learning to support transdisciplinarity in an HCI. In Proceedings of HCled (HCI in education) conference (p. 94).
Association for Computing Machinery, Denmark.

Rosario, B. I. 2009. Science, Technology, Society and Environment (STSE) Approach in Environmental Science for Nonscience Students in a Local Culture. Liceo Journal of Education Research, Vol.6, No.1, 269281.

Setiawati, I. K. 2015. Pengembangan Perangkat Pembelajaran IPA Berbasis SETS untuk Meningkatkan Scientific Literacy dan Foundational Knowledge Peserta Didik SMP. Tesis. Universitas Negeri Yogyakarta, Yogyakarta.

Wellington, J., \& Ireson, G. 2012. Science Learning, Science Teaching (Third Edition). New York: Routledge.

Wilujeng, I. 2011. Membentuk Siswa yang Memiliki Literasi Sains dan Berkarakter Melalui Pendekatan Pembelajaran STSE. Yogyakarta: Jurusan Pendidikan Fisika UNY.

Yager, R. E., \& Akcay, H. 2008. Comparison of Student Learning Outcomes in Middle School Science Classes with an STS Approach and a Typical Textbook Dominated Approach. RMLE Online, 31(7), 1-16.

Yager, R. E., Choi, A., Yager, S. O., \& Akcay, H. 2009. Comparing Science Learning Among 4th, 5th, and 6th - Grade Students: STS Versus Textbook -Base Instruction. Jornal of Elementary Science Education, 21(2), 15-24.

Yager, S. O., Dogan, O. K., Hacieminoglu, E., \& Yager, R. E. 2012. The Role of Student and Teacher Creativity in Aiding Current Reform Efforts in Science and Technology Education. National Forum of Applied Educational Research Journal, 25(3), 1-24.

Yager, S. O., Yager, E. R., \& Lim, G. 2006. The Advantage of an STS Approach Over a Typical Textbook Dominated Approach in Midle Scool Science. School Science and Mathematics, 106(5), 248-260. 
Yörük, N., Morgil, I., \& Seçken, N. 2010. The effects of science, technology, society, environment (STSE) interactions on teaching chemistry. Natural Science, 2(12), 1417-1424. 